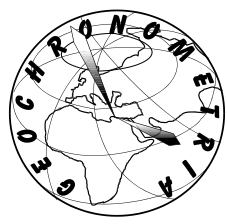

Conference Proceedings of the $5^{\text {th }}$ Asia Pacific Luminescence and Electron Spin Resonance Dating Conference October $15^{\text {th }}-17^{\text {th }}$, 2018, Beijing, China

Guest Editor: Grzegorz Adamiec

\title{
LUMINESCENCE DATING OF LACUSTRINE SEDIMENTS FROM CUOE LAKE ON THE CENTRAL TIBETAN PLATEAU
}

\author{
YANDONG HOU ${ }^{1,3}$, HAO LONG $^{1,2}$, LEI GAO ${ }^{1}$ and JI SHEN ${ }^{1}$ \\ ${ }^{I}$ State Key Laboratory of Lake Science and Environment, Nanjing Institute of Geography and Limnology, \\ Chinese Academy of Sciences (NIGLAS), Nanjing 218000, China \\ ${ }^{2}$ CAS Center for Excellence in Quaternary Science and Global Change, Chinese Academy of Sciences, Xi'an 710061, China \\ ${ }^{3}$ University of Chinese Academy of Sciences, Beijing 100049, China
}

Received 16 January 2019

Accepted 2 March 2020

\begin{abstract}
Luminescence dating technology has been used for chronological constraints on lacustrine sediments due to the ubiquitous materials (e.g., quartz and feldspar) as dosimeters, and a relatively long dating range, compared with the commonly used radiocarbon dating method. However, quartz dating on the Tibetan Plateau may suffer from dim and unstable luminescence signals. In the current study, we investigate a lake-related outcrop from the shore of Cuoe Lake on the central Tibetan Plateau. Both coarse-grained quartz and K-feldspar fractions were extracted, and OSL and post-IR IRSL signals were measured from these fractions, respectively. Combining the stratigraphy analysis and dating results, this study shows that: (1) quartz appears to be unsuitable for dating because of very dim natural signals and even anomalous fading (average $g$-value: $4.30 \pm 2.51 \% /$ decade). The suitability of the applied pIRIR protocol measured at $150^{\circ} \mathrm{C}\left(\mathrm{pIRIR}_{150}\right)$ for K-feldspar samples was confirmed by a set of luminescence tests; (2) compared with the luminescence-based chronology, the ${ }^{14} \mathrm{C}$ age of shells from the same sediment layer yielded older age by $\sim 7 \mathrm{ka}$, which is likely attributed to hard water reservoir effect in Cuoe Lake; (3) the lake level reached its peak and maintained high-stand during the early Holocene ( 9.4-7.1 ka). This study highlights the applicability of K-feldspar luminescence dating when the counterpart quartz OSL is insensitive and encounters anomalous fading.
\end{abstract}

Keywords: luminescence dating, anomalous fading, lacustrine sediments, Tibetan Plateau, Holocene.

\section{INTRODUCTION}

The Tibetan Plateau (TP), known as the "Water Tower of Asia" and "the Third Pole", is highly relevant to Asian monsoon systems (East Asian monsoon and Indian

Corresponding author: H. Long

e-mail: longhao@niglas.ac.cn monsoon), and global climate change due to its massive extension at high altitudes (Krause et al., 2010; Song et al., 2013). Instrumental data have recorded rapid warming during recent decades in this region, approximately three times faster than that of the global average (Zhang et al., 2017). Long-term records derived from paleoclimatic proxies are invaluable for improving our understanding of the natural range and causes of variability in regions compared with instrumental records. There are over 1000 lakes (larger than $1 \mathrm{~km}^{2}$ ) distributed across the 
TP (Wang and Dou, 1998; Ma et al., 2011). The storage of water in a closed lake basin reflects the balance between evaporation and water influx, referring to both runoff and direct precipitation (Benson and Paillet, 1989), and it has typically been used to infer the variation history in the regional effective moisture (e.g., Long et al., 2012; Zhang et al., 2016). Outcrops and landforms can provide direct evidence of sediment facies changes, and record details of lake-level fluctuations, geologic events such as catastrophic floods, drainage-basin changes and isostatic rebound (Reheis et al., 2014).

Several studies have been conducted to document the paleoenvironmental change on the TP by dating relict beach ridges and lacustrine sediments with optically stimulated luminescence (OSL), cosmogenic radionuclides and ${ }^{14} \mathrm{C}$ methods (e.g., Kong et al., 2011; Long et al., 2012; Chen et al., 2013; Ahlborn et al., 2016; Alivernini et al., 2018). Particularly, the OSL method has increasingly been applied to lacustrine deposits, owing to readily available dating materials, i.e., quartz and feldspar. However, the problem of very dim natural and regenerative OSL signals from quartz samples has been reported in this region (Long et al., 2015); this makes it difficult to obtain reliable age solely using quartz (Long et al., 2015; Preusser et al., 2009). Moreover, anomalous fading rates of $2-4 \%$ /decade have been measured on beach sands from Tangra Yum Co on the southern Tibetan Plateau (Rades et al. 2015). Several reconstructions of the past lake levels in the catchment of Selin Co (Fig. 1a) based on OSL dating of the exposed paleoshorelines have yielded obviously inconsistent results. Li et al. (2009) and Xue et al. (2010) reported that the lake dropped at the periods of $\sim 12-9 \mathrm{ka}, \sim 7-6 \mathrm{ka}$ and $2 \mathrm{ka}$, but Shi et al. (2017) claimed a highstand through the period between $\sim 8$ and $\sim 4 \mathrm{ka}$. Those disagreements and uncertainties concerning the temporal patterns of past paleohydrological changes in this region could limit our understanding of the associated forcing mechanisms and the extent to which climate patterns could shift in response to future climate change (Hou et al., 2012).

In this paper, we carried out a combined stratigraphic and chronological analysis on a lacustrine outcrop from Cuoe Lake on the central TP. Both luminescence and radiocarbon dating methods were used to reconstruct the evolution of the lake level during the Holocene.

\section{STUDY AREA AND RESEARCH MATERIAL}

Selin Co Basin (Fig. 1a and inset) is located in the central part of the TP and contains several large lakes (e.g., Selin Co and Cuoe Lake); those lakes are presently connected through rivers. The largest lake in the basin is Selin Co $\left(30^{\circ} 7^{\prime}-33^{\circ} 17^{\prime} \mathrm{N}, 87^{\circ} 27^{\prime}-92^{\circ} 12^{\prime}\right.$ E) (Fig. 1b), with the drainage area of $\sim 57,200 \mathrm{~km}^{2}$ and surface area of $\sim 2,320 \mathrm{~km}^{2}$. The elevation in the basin ranges from 4532 to $6406 \mathrm{~m}$ above sea level (Shi et al., 2017). There are four major subbasins (i.e., Zhajia River, Zhagen River,
Ali River and Boqu River) with runoff inflows into the lake. The Zhajia River originating from the Tanggula Mountains has the largest drainage area of $\sim 16,130 \mathrm{~km}^{2}$, and the other three have areas of $16,073 \mathrm{~km}^{2}$ (Zhagen River), 6,859 $\mathrm{km}^{2}$ (Ali River) and 1,154 $\mathrm{km}^{2}$ (Boqu River), respectively (Tong et al., 2016). The annual average precipitation is approximately $315 \mathrm{~mm}$ and mainly occurs from May to September (Zhou et al., 2015). The climate of the basin is dry and cold, with a mean annual temperature of $0.7^{\circ} \mathrm{C}$, relative humidity of $42 \%$, and wind speed of $3.9 \mathrm{~m} / \mathrm{s}$ from 1961-2009 (Zhang et al., 2011). The water level of Selin Co is dominantly regulated by the regional precipitation associated with the southwest Indian monsoon (Shi et al., 2017). Cuoe Lake and Selin Co have once existed as a large uniform lake with high-stand status (Zhu et al., 2004). The studied profile (CE1, Fig. 1b) was exposed due to the incision of a stream flowing into this lake.

The CE1 site $\left(31^{\circ} 30^{\prime} 29^{\prime \prime} \mathrm{N}, 88^{\circ} 48^{\prime} 20^{\prime \prime} \mathrm{E}\right)$ is about $\sim 18 \mathrm{~m}$ above present lake level (a.p.l.1.), and the $\sim 2 \mathrm{~m}$ thick section exhibits significant variations in sedimentary composition and structure. It can roughly be divided into three stratigraphic units (U1 from the bottom, U2 in

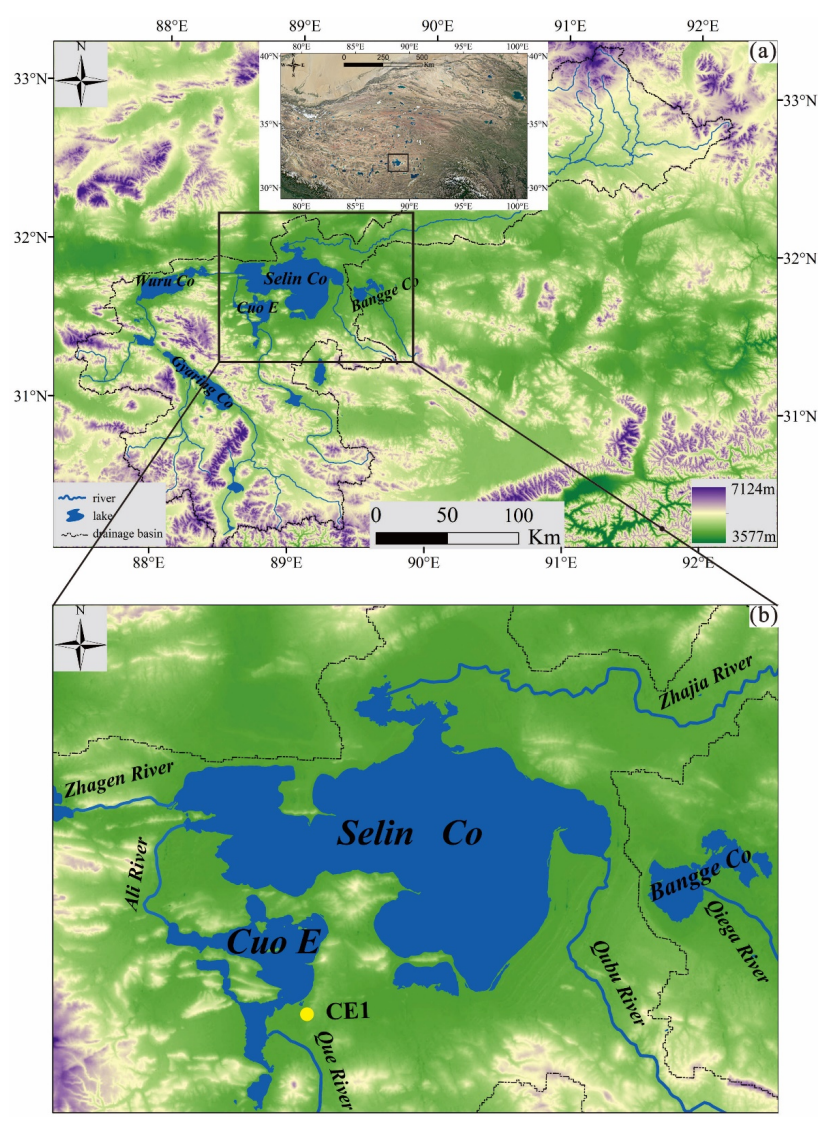

Fig. 1. (a) Map showing the distibution of major rivers flowing to Selin Co and Google Earth satellite image showing the locations of Selin Co and Cuoe lake (inset); (b) Location of CE1 profile. The base map in (a) and (b) were obtained from http://www.gscloud.cn/. 
the middle and U3 from the top) by apparent unconformities (Fig. 2). The lower part of U1 consists of coarse wellrounded, clast-supported pebbles with a thickness of $0.5 \mathrm{~m}$ (exposed part); its upper part consists of fine sand intercalated with a few pebbles characterised by slightly parallel laminations; this suggests shoreline deposits formed during high-energy processes. U1 is overlain by U2 with nearly sharp contact; U2 ( 2 m thick) is mainly composed of fine sand with sheet-like, plane-parallel laminations which can be observed over $20 \mathrm{~m}$ in horizontal extent; a striking feature of this unit is the presence of shells. The occurrence of shells rich sediments and planeparallel laminations indicates that sediments were deposited in a typical lacustrine environment. The massive fine-grained sands in U3 are 1-2 m thick and are characteristic for fluvial channel deposits; the unit has a concave-up basal scour with low topographic relief, deposited under fluvial conditions. To build up a chronology of the CE1 profile, six samples were collected with steel tubes for luminescence dating. Additionally, for radiocarbon dating two shell samples (Beta-471695 and Beta471698) were also taken, one from the CE1 section $(162 \mathrm{~cm}$ depth) and another in a modern shoreline from a different location.

\section{DATING METHODS}

\section{Sample preparation}

All luminescence samples' preparation and measurement were performed at the Luminescence Dating Laboratory of NIGLAS (Nanjing, China). In subdued red light, the daylight-exposed outer layer of the samples was scraped off for water content and dose rate measurements. The remaining (un-exposed) material was prepared for the equivalent dose $\left(D_{e}\right)$ measurements.

These six samples were wet sieved to extract the coarse grain size fraction $(63-90 \mu \mathrm{m}$ or $100-200 \mu \mathrm{m})$.
Samples were firstly treated with $30 \% \mathrm{H}_{2} \mathrm{O}_{2}$ and $10 \%$ $\mathrm{HCl}$ to remove organic material and carbonates, respectively. Subsequently, the K-rich feldspar fraction $\left(<2.58 \mathrm{~g} / \mathrm{cm}^{3}\right)$, and the quartz-rich fraction $(2.62-2.70$ $\mathrm{g} / \mathrm{cm}^{3}$ ) were separated with a heavy liquid solution (sodium polytungstate). The quartz grains were etched with $40 \%$ hydrofluoric (HF) acid for one hour to remove the outer alpha-irradiated layer of the quartz and to eliminate feldspar contamination, and then the etched fraction was rinsed with $10 \% \mathrm{HCl}$ to remove fluoride. Considering that HF etching on feldspar tends to attack the cleavage planes of the mineral grains, instead of removing the outer rim uniformly (Duller, 1994), we did not etch the K-feldspar grains with HF. Instead, we took the external alpha-irradiated dose rate of the feldspar grains into account for total dose rate calculation. The pure quartz and $\mathrm{K}$-feldspar grains were mounted as $6 \mathrm{~mm}$ and $2 \mathrm{~mm}$ diameter monolayers respectively on $9.8 \mathrm{~mm}$ diameter stainless steel discs using silicone oil as an adhesive for measurements.

$D_{e}$ values were measured with an automated luminescence reader (Risø TL/OSL DA-20) equipped with a ${ }^{90} \mathrm{Sr} /{ }^{90} \mathrm{Y}$ beta source. For quartz OSL, blue LEDs $(470 \mathrm{~nm})$ were used for stimulating the aliquots and a 7.5-mm Hoya U-340 filter was used as the signal detection filter in front of the photomultiplier tube. For the infrared (IR) stimulation of K-feldspar, infrared LEDs $(870 \mathrm{~nm})$ were used and the infrared-stimulated luminescence (IRSL) signal was detected through a combination of Schott BG-39 and BG-3 filters in the blue-violet spectrum between 320 and $450 \mathrm{~nm}$.

\section{Dose rate determination}

Approximately $60 \mathrm{~g}$ of sediments from each luminescence sample were dried for 4 days at $50^{\circ} \mathrm{C}$ until constant weight to determine the present-day water content. The dried material was homogenised, and a subsample of $5 \mathrm{~g}$

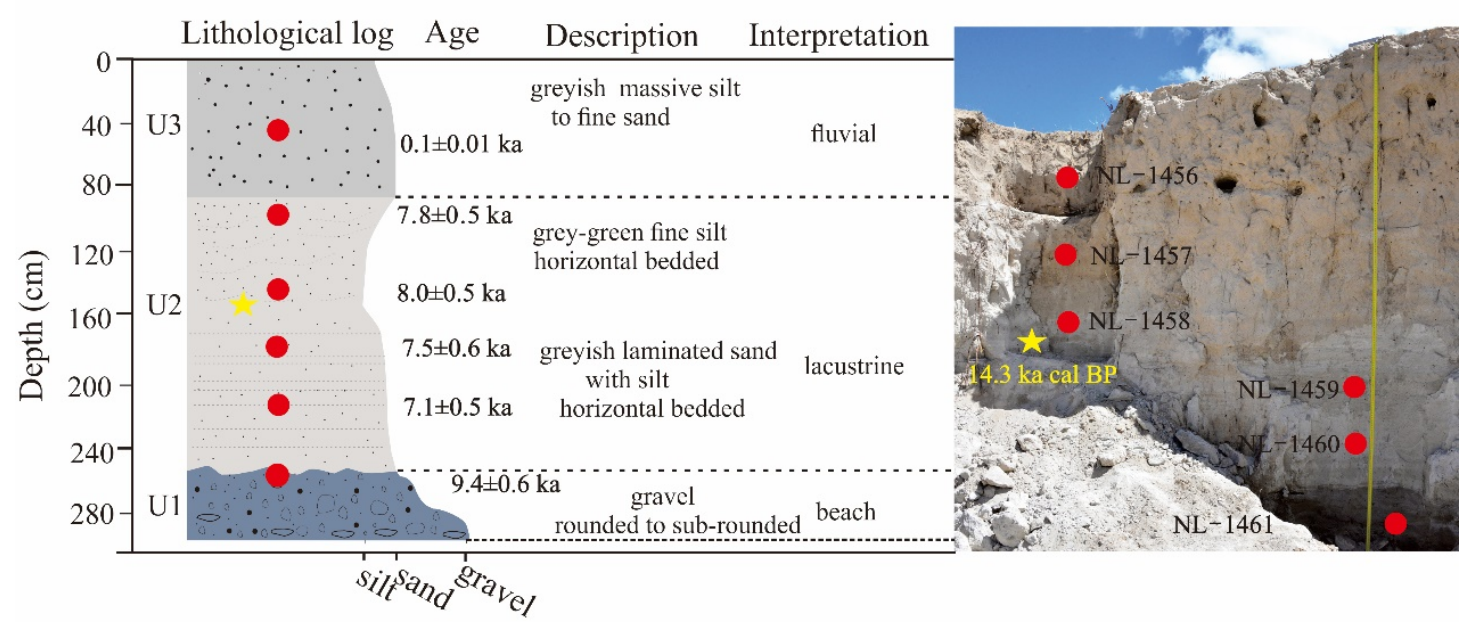

Fig. 2. Photo and sedimentary log of section CE1. 
was ground to powder for the measurement of dose rate related elements, i.e., uranium (U), thorium (Th) and potassium (K), using neutron activation analysis (NAA) at the China Institute of Atomic Energy in Beijing. The cosmic ray contribution to dose rate for each example was estimated as a function of depth, altitude and geomagnetic latitude (Prescott and Hutton, 1994). An $\alpha$-value of $0.15 \pm 0.05$ is used according to Balescu and Lamothe (1994) for external $\alpha$-dose rate calculation of the outer $0.25 \mathrm{~mm}$ (following Aitken, 1998) of the feldspar grains. For the internal $\beta$-dose rate, a $\mathrm{K}$ concentration of $12.5 \pm 0.5 \%$ (Huntley and Baril, 1997) and an Rb content of $400 \mu \mathrm{g} / \mathrm{g}$ (following Huntley and Hancock, 2001) are assumed. Finally, the total dose rates were calculated using the conversion factors of Guérin et al. (2011). We used the water contents measured from fresh sediments with an uncertainty of $10 \%$ for dose rate calculation of all samples.

\section{Measurement protocol for equivalent dose estimation}

The $D_{\mathrm{e}}$ of $C G$ quartz was determined using a routine single-aliquot regenerative-dose (SAR) protocol (Murray and Wintle, 2000) with an additional step of IR depletion to monitor feldspar contamination (Duller, 2003) in the SAR sequence. A previous study pointed out anomalous fading on quartz samples from an adjacent region (Rades et al., 2015). Thus, we carried out an anomalous fading test according to the procedure described by Auclair et al. (2003).

Thomsen et al. (2008) firstly proposed the potential of an elevated temperature pIRIR SAR protocol. Afterwards, Madsen et al. (2011) modified and applied this protocol (Table 1). This study measured the IRSL signal at $50^{\circ} \mathrm{C}\left(\mathrm{IRSL}_{50}\right)$ for $100 \mathrm{~s}$, followed by another IRSL measurement at an elevated temperature at $150^{\circ} \mathrm{C}$ $\left(\mathrm{pIRIR}_{150}\right)$ for $100 \mathrm{~s}$. For both the pIRIR 150 and $\mathrm{IRSL}_{50}$ signals, intensities were calculated from the initial $10 \mathrm{~s}$,

Table 1. Protocol used to measure pIRIR150.

\begin{tabular}{clc}
\hline Step & Treatment & Observed \\
\hline 1 & Dose & \\
\hline 2 & Preheat at $180^{\circ} \mathrm{C}$ for $60 \mathrm{~s}$ & $\mathrm{Lx} 1$ \\
\hline 3 & $\mathrm{IRSL}$ measurement at $50^{\circ} \mathrm{C}$ for $100 \mathrm{~s}$ & $\mathrm{Lx} 2$ \\
\hline 4 & $\mathrm{IRSL}$ measurement at $150^{\circ} \mathrm{C}$ for $200 \mathrm{~s}$ & \\
\hline 5 & Test dose & $\mathrm{Tx} 1$ \\
\hline 6 & Preheat at $180^{\circ} \mathrm{C}$ for $60 \mathrm{~s}$ & $\mathrm{Lx} 2$ \\
\hline 7 & IRSL measurement at $50^{\circ} \mathrm{C}$ for $100 \mathrm{~s}$ & \\
\hline 8 & IRSL measurement at $150^{\circ} \mathrm{C}$ for $200 \mathrm{~s}$ & \\
\hline 9 & Return to step 1 &
\end{tabular}

less a background derived from the last $10 \mathrm{~s}$ to make it suitable for young samples.

\section{Radiocarbon dating}

Radiocarbon dating was determined at Beta Analytic. The samples were processed using a conventional acidalkali-acid treatment to remove carbonate and other contaminants. The alkali-insoluble organics were obtained and then prepared as graphite for AMS radiocarbon measurements. The measured ${ }^{14} \mathrm{C}$ ages were calibrated to calendar years using the CALIB program with the IntCal 13 dataset after ${ }^{13} \mathrm{C} /{ }^{12} \mathrm{C}$ adjustment (Reimer et al., 2013) (Table 2).

\section{RESULTS AND DISCUSSION}

\section{Luminescence characteristics}

Fig. 3a demonstrates the decay curve of CG quartz OSL signals for one representative example (NL-1457), showing a minimal natural OSL signal. Similarly, other CG quartz samples also showed very dim natural and regenerated OSL signals. Only several tens of counts for the first $0.16 \mathrm{~s}$ of stimulation were obtained when a test dose of $\sim 10$ Gy was applied. Meanwhile, anomalous fading tests were conducted on quartz grains of the six samples (four aliquots for each) from CE1. Unexpectedly, we found anomalous fading rates of 2-9\%/decade (mean $4.30 \pm 2.51 \% /$ decade) in our quartz samples (Fig. $4 \mathrm{a}$ and 4b). In addition, we carried out an anomalous fading test on Risø calibration quartz (Hansen et al., 2015) with an average result $-0.90 \pm 0.41 \% /$ decades (Fig. $4 \mathbf{c}$ and $4 d$ ). Compared with calibration quartz, we conclude that the quartz samples from CE1 suffer from anomalous fading. Until now, there is no reliable method to fading correction of quartz ages (Rades et al., 2015). Therefore, we only use the pIRIR measurement of K-feldspar fraction to set up the chronological framework for the sediments of Cuoe Lake. Fig. 3b shows an example (NL-1457) for a natural IRSL $\mathrm{I}_{50}$ decay curve and the subsequently measured pIRIR ${ }_{150}$ decay curve for the same aliquot.

In order to confirm the suitability of the used measurement protocol, it is commonly accepted that three routine tests should be carried out for any new SAR protocol, i.e., the examination of the recycling ratio, recuperation and dose recovery tests (DRT) (Murray and Wintle, 2000; Buylaert et al., 2009). Fig. 5a summarises the recycling ratios for the pIRIR ${ }_{150}$ signal. The mean recycling ratio for all samples in this study is $1.10 \pm 0.01$, illustrating that the sensitivity correction is not so good

Table 2. Summary of the AMS ${ }^{14} \mathrm{C}$ ages.

\begin{tabular}{lcccc}
\hline Sample ID & $\begin{array}{c}\text { Depth } \\
(\mathbf{c m})\end{array}$ & Material & $\begin{array}{c}\text { Radiocarbon Age } \\
(\mathbf{a ~ B P})\end{array}$ & $\begin{array}{c}\text { Calibrated Radiocarbon age } \\
\text { (cal ka BP) }\end{array}$ \\
\hline Beta-471695 & 162 & shell & $13060 \pm 30$ & $15.6 \pm 0.1$ \\
Beta-471698 & 0 & shell & $1320 \pm 30$ & $1.3 \pm 0.04$ \\
\hline
\end{tabular}



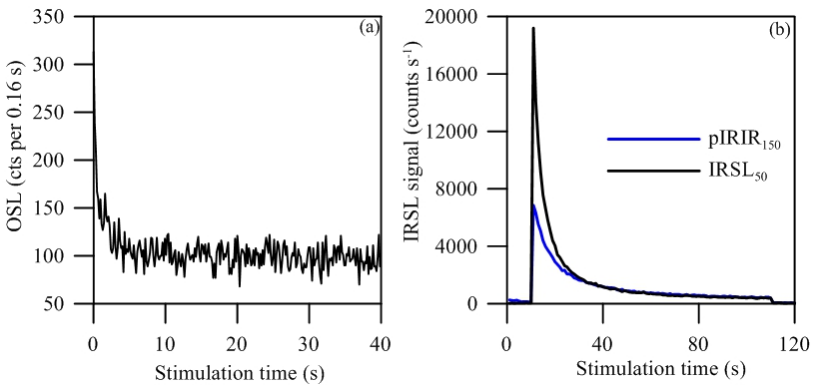

Fig. 3. (a) The example decay showing very low natural quartz OSL signals; (b) Typical IRSL and pIRIR decay curves of K-feldspar of sample NL-1457.
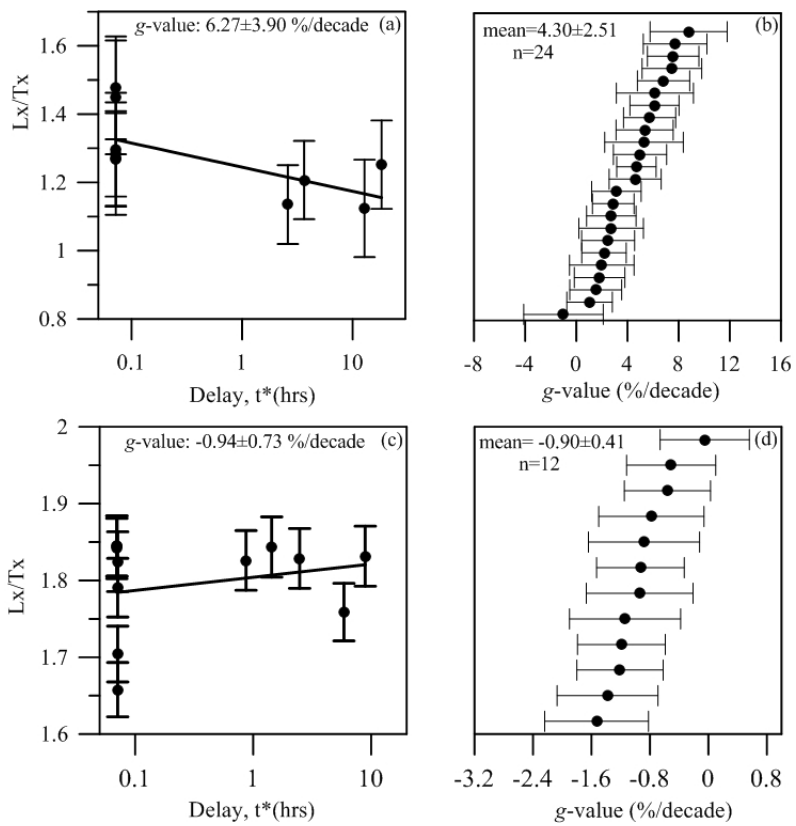

Fig. 4. (a) Fading rate (g-value) of CG quartz for a representative aliquot (NL-1456); (b) Summary of g-values of 24 aliquots from all samples; (c) The g-value determination for standard quartz sample; (d) Summary of g-values of standard quartz samples.

but acceptable; the relatively high recycling ratios were probably due to lacking of elevated temperature cleanout at the end of our SAR cycles. Fig. 5b summarises the recuperation values, suggesting less than $5 \%$ for most measured aliquots (mean $=3.50 \pm 0.17 \%$ ), which are considered relatively small.

Furthermore, dose recovery tests were undertaken for all six samples (three aliquots for each). First, the aliquots were bleached with a solar simulator (Hönle SOL2) lamp for $4 \mathrm{~h}$ (e.g., Reimann and Tsukamoto, 2012; Buylaert et al., 2012). They were then given a beta-dose of $\sim 30 \mathrm{~Gy}$ and measured using the pIRIR protocol. The DRT results of all six samples are presented in Fig. 5c, showing that measured-to-given dose ratios for $\mathrm{pIRIR}_{150}$ signal ranged between 0.9 and 1.1 after subtracting the residual dose mentioned below. This further confirms that the SAR protocol applied to the pIRIR signals appears to be satisfactory.

It is well known that most feldspar samples suffer from anomalous fading. Huntley and Lamothe (2001) showed that the luminescence signal decayed linearly with the logarithm of time and attributed this loss to anomalous fading which is usually quantified by the $g$ value. We determined fading rates ( $g$-value) for $\operatorname{pIRIR}_{150}$ signals as well as IRSL 50 using the procedure of Auclair et al. (2003). Fig. 6a and Fig. 6b show the $g$-values for both pIRIR $_{150}$ and IRSL $_{50}$ signals of a representative sample (NL-1459), ranging from 0.9 to $1.44 \% /$ decade and from 2.3 to $3.4 \%$ /decade, respectively. The pIRIR ${ }_{150}$ and IRSL $_{50} g$-value for all discs are summarised as histograms in Fig. 6c and Fig. 6d. The mean pIRIR ${ }_{150} g$-value is $1.44 \pm 0.80 \% /$ decade, which is much lower than the mean $\mathrm{IR}_{50} g$-value of $3.16 \pm 0.74 \%$ /decade. Thus, we propose that the use of the pIRIR ${ }_{150}$ signal is able to reduce anomalous fading even to a negligible level, and so we used the measured $D_{e}$ values derived from the pI$\mathrm{RIR}_{150}$ signal for luminescence age calculation. Because the laboratory fading experiments should not be considered as convincing evidence for loss of trapped charge during storage, especially for such low fading rates of $1.0-1.5 \% /$ decade; possibly these low apparent fading rates are an artefact of inaccurate sensitivity correction after storage (Buylaert et al., 2012; Roberts, 2012).
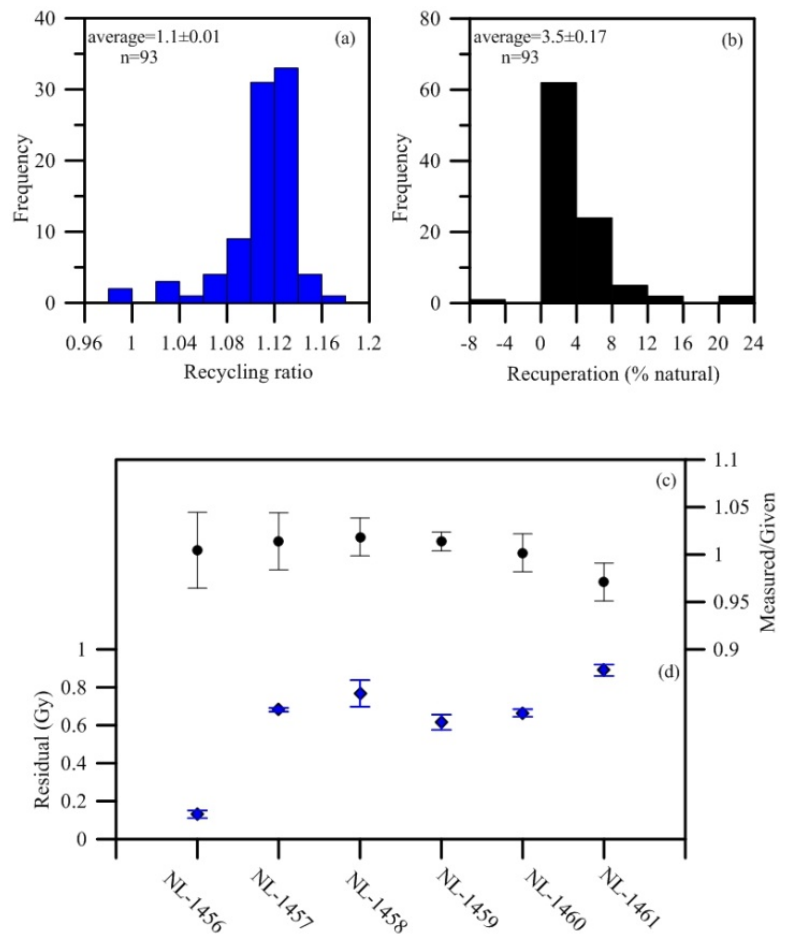

Fig. 5. Histograms summarizing the recycling ratios (a) and recuperation values (b) of pIRIR150 measurements; Dose recovery ratio (c) and residual dose (d) on pIRIR 150 signal for the six samples. 
In order to investigate bleaching behaviour for the pIRIR $_{150}$, residual doses were first measured using three aliquots for each sample after exposure to Hönle 2 for $4 \mathrm{~h}$ (Zhang et al., 2015). The tests showed that the residual doses range between 0.6 and 0.9 Gy (Fig. 5d), corresponding to $\sim 200-300$ years, which are considered as very young and even negligible compared with the Holocene age-scale of the current study. In addition, it is well known that for feldspar luminescence the elevated temperature IRSL bleaches more slowly than IRSL stimulated at low temperature (Murray et al., 2012; Buylaert et al., 2012; Reimann and Tsukamoto, 2012); thus the comparison of $\mathrm{D}_{\mathrm{e}} \mathrm{s}$ derived from signals with different bleaching rates has also been applied to examine the bleaching situation. As shown in Fig. 7, the ratios of $\mathrm{IR}_{50}$ to pIRIR $_{150}$ doses generally lie on a smooth curve below a slope of 1; this meets the criterion of Buylaert et al. (2013) for identifying well-bleached sediments. Thus, we deduce that the pIRIR ${ }_{150}$ signals of our samples should be bleached prior to deposition.

For each sample, 12-24 aliquots were used for $D_{e}$ measurement. All $\mathrm{D}_{\mathrm{e}} \mathrm{s}$ estimates derived from the pIRIR $_{150}$ signal for the six samples are listed in Table 3, and after that, $\mathrm{D}_{\mathrm{e}} \mathrm{s}$ were divided by dose rates derived from NAA measurements to obtain luminescence ages.

\section{Comparison between luminescence and ${ }^{14} \mathrm{C}$ ages}

It is essential to compare the data generated using luminescence with an independent age control (e.g., ${ }^{14} \mathrm{C}$ dating). Terrestrial plant macrofossils are well known to be most suitable for radiocarbon dating of lake sediment, as they are not affected by old carbon reservoir effects (Long et al., 2011). Unfortunately, macroscopic fossils of terrestrial plants are lacking in this profile probably due to the very low vegetation cover. The luminescence and ${ }^{14} \mathrm{C}$ ages of a sediment layer from CE1 section reveal an apparent offset between two kinds of dating methods by $\sim 7 \mathrm{ka}$, which might be caused by the age overestimate of ${ }^{14} \mathrm{C}$ dating due to a reservoir effect in the study. As a previous study reported (Hou et al., 2012), the reservoir effects vary significantly from one lake to another over the TP, e.g., changing from 650 years (Ahung $\mathrm{Co}$ ) to 6670 years (Bangong Co). In this study, the luminescence dating results revealed a reservoir effect of $\sim 7 \mathrm{ka}$ for the early Holocene sedimentary unit, which appears much larger than that of modern sediments, i.e. $\sim 1.3$ cal ka BP. This probably suggested temporal variation of reservoir effects in the same lake. The similar results from the same sediment core or profile have already been pointed out in the other lakes on Tibetan Plateau areas (e.g., An $e t$ al., 2012; Hou et al., 2012; Long et al., 2012). Therefore, the robust luminescence ages may provide a way to estimate the ${ }^{14} \mathrm{C}$ age reservoir effect of lake sediments.

Table 3. Luminescence dating results for six samples from CE1 profile.

\begin{tabular}{|c|c|c|c|c|c|c|c|c|c|c|}
\hline $\begin{array}{l}\text { Section } \\
\text { name }\end{array}$ & $\begin{array}{c}\text { Sample } \\
\text { ID }\end{array}$ & $\begin{array}{r}\text { Depth } \\
(\mathrm{cm})\end{array}$ & $\underset{(\mathrm{ppm})}{\mathrm{U}}$ & $\begin{array}{c}\text { Th } \\
(\mathrm{ppm})\end{array}$ & $\begin{array}{c}\mathrm{K} \\
(\%)\end{array}$ & $\begin{array}{c}\text { Water } \\
\text { Content } \\
(\%) \\
\end{array}$ & $\begin{array}{r}\text { Cosmic } \\
\text { dose rate } \\
(G y / k a) \\
\end{array}$ & $\begin{array}{r}\text { Total } \\
\text { dose rate } \\
(\text { Gy/ka) }\end{array}$ & $\begin{array}{c}D_{\mathrm{e}} \\
\text { (Gy) }\end{array}$ & $\begin{array}{l}\text { Age } \\
\text { (ka) }\end{array}$ \\
\hline \multirow{6}{*}{ CE1 } & NL-1456 & 40 & $2.63 \pm 0.10$ & $9.81 \pm 0.28$ & $1.59 \pm 0.05$ & $4.16 \pm 10$ & $0.42 \pm 0.04$ & $3.92 \pm 0.25$ & $0.45 \pm 0.04$ & $0.1 \pm 0.01$ \\
\hline & NL-1457 & 90 & $2.1 \pm 0.09$ & $7.02 \pm 0.22$ & $1.00 \pm 0.04$ & $10.70 \pm 10$ & $0.39 \pm 0.04$ & $3.72 \pm 0.26$ & $29.70 \pm 0.2$ & $7.9 \pm 0.5$ \\
\hline & NL-1458 & 150 & $3.89 \pm 0.14$ & $9.58 \pm 0.28$ & $1.44 \pm 0.05$ & $10.86 \pm 10$ & $0.36 \pm 0.04$ & $4.08 \pm 0.26$ & $33.23 \pm 0.4$ & $8.0 \pm 0.5$ \\
\hline & NL-1459 & 170 & $5.87 \pm 0.21$ & $6.85 \pm 0.23$ & $1.03 \pm 0.04$ & $30.74 \pm 10$ & $0.35 \pm 0.04$ & $3.56 \pm 0.25$ & $27.49 \pm 0.6$ & 7. $6 \pm 0.6$ \\
\hline & NL-1460 & 210 & $6.67 \pm 0.21$ & $6.2 \pm 0.20$ & $0.85 \pm 0.04$ & $29.88 \pm 10$ & $0.33 \pm 0.03$ & $3.52 \pm 0.26$ & $25.13 \pm 0.2$ & $7.1 \pm 0.5$ \\
\hline & NL-1461 & 245 & $2.71 \pm 0.11$ & $9.45 \pm 0.27$ & $1.61 \pm 0.05$ & $2.48 \pm 10$ & $0.32 \pm 0.03$ & $3.68 \pm 0.24$ & $34.69 \pm 0.3$ & $9.4 \pm 0.6$ \\
\hline
\end{tabular}
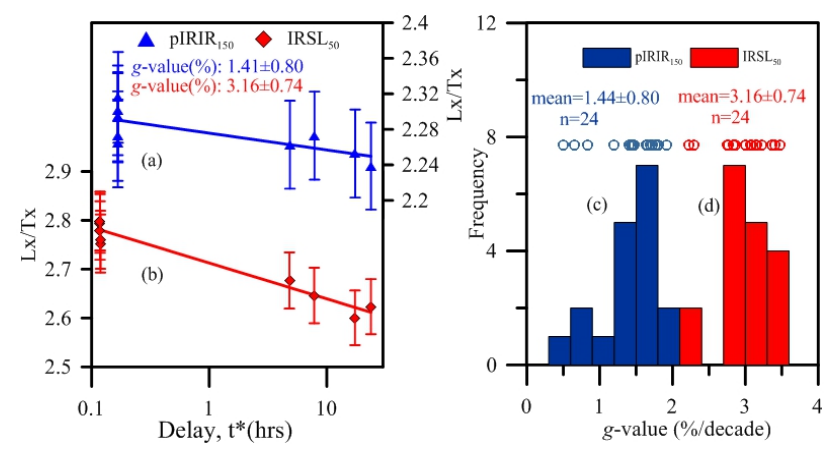

Fig. 6. A g-value determination of CG K-feldspar pIRIR 150 in (a) and IRSL50 in (b) signals for a representative aliquots; Histogram summarizing pIRIR 150 in (c) and IRSL50 (d) fading rates for all six samples (four aliquots for each sample).

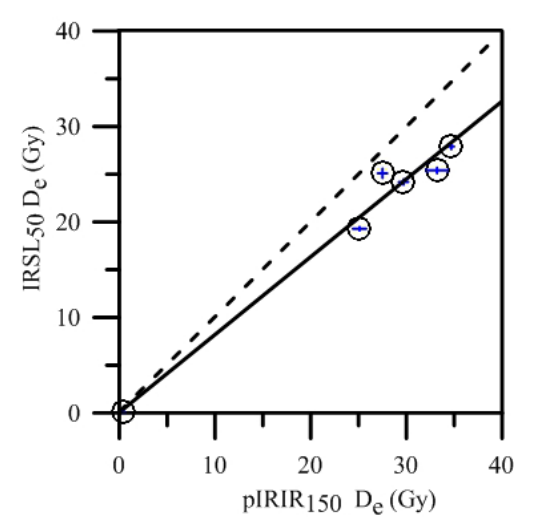

Fig. 7. Comparison between mean $D_{e} S$ of $I R S L_{50}$ and pIRIR 150 signals for six samples. 


\section{The chronostratigraphy of CE1 section and its impli- cations on lake-level evolution}

Based on the luminescence dating and stratigraphic analysis, we constructed the chronostratigraphy of the CE1 section (Fig. 2). Before $~ 9.4 \mathrm{ka}$, the beach deposits in CE1 indicated that the lake level nearly reached at $\sim 16 \mathrm{~m}$ (a.p.l.1.). The lacustrine sediment formed between $9.4 \pm 0.6 \mathrm{ka}$ and $7.1 \pm 0.5 \mathrm{ka}$, suggesting that the lake began extension and remained a relatively high lake-level (above $\sim 18 \mathrm{~m}$ a.p.l.1.). A prominent lake-level drop after $7.1 \mathrm{ka}$ is indicated by a clear erosional surface followed by a layer of fluvial sediment dated to $\sim 0.1 \mathrm{ka}$. Our results are overall in phase with other published hydroclimate records from Selin Co. The isotope data provided evidence that the lake rose and expanded to reach its highstand condition from $\sim 10.5-9.5 \mathrm{ka}$ (Gu et al., 1993; Kashiwaya et al., 1995). Similarly, a slight increase in the lake level from $\sim 11$ to $8 \mathrm{ka}$ was observed based on TOC content (Gyawali et al., 2019). The pattern of a high and stable lake during the early Holocene and relatively low lake level in the middle to late Holocene unveiled in Selin Co and other adjacent geological archives can be comparable with Indian Summer Monsoon (ISM) precipitation reconstructions derived from stalagmite $\delta^{18} \mathrm{O}$ (e.g., Tianmen Cave, Cai et al., 2012). He et al. (2017) investigated Linggo Co on the central TP and contended that the ISM had been strengthened significantly between 10 and $7 \mathrm{ka}$ according to the leaf wax $\delta \mathrm{D}$ record. The TOC record from alpine wetland sequence (Dangxiong County) on central TP suggested wetland initiation at approximately between $8.7 \mathrm{ka}$ and $7.2 \mathrm{ka}$, as an indicator of increased monsoon precipitation (Cheung et al., 2017). An early Holocene lake level maximum around 9-8 $\mathrm{ka}$ is also recorded for many lakes of the southern Tibetan Plateau (Kasper et al., 2015; Ahlborn et al., 2016). During the Middle to Late Holocene, the relatively low lake level might be related to the lower effective moisture which has been resulted by weakened monsoon (Herzschuh, 2006).

\section{CONCLUSION}

This study reconstructed the sedimentary history of Cuoe Lake, mainly based on luminescence dating of outcrop CE1, and then lake level fluctuations were inferred. Luminescence characteristic tests show that quartz OSL signal is too dim to date and even suffers from anomalous fading, which limits the application of quartz mineral. Alternatively, the suitability of the pIRIR protocol measured at $150^{\circ} \mathrm{C}\left(\mathrm{pIRIR}_{150}\right)$ for K-feldspar fractions is confirmed by a set of luminescence tests. Compared with luminescence age, ${ }^{14} \mathrm{C}$ dating of a shell sample recovered from the lake sediments yields much older age by $\sim 7 \mathrm{ka}$, which might be a result of hardwater reservoir effect. Combining the luminescence-based chronology and sedimentary analysis, we conclude that the Cuoe Lake has experienced peak water-level during the early
Holocene ( 9.4-7.1 ka), and lake-level drop afterwards; this lake-level variation pattern is probably related to the changes of the dominant summer monsoon system.

\section{ACKNOWLEDGEMENTS}

This research was funded by the Strategic Priority Research Program of Chinese Academy of Sciences (No. XDB40010200) and the Program of Global Change and Mitigation (grant No. 2016YFA0600502), the National Natural Science Foundation of China (No. 41977381 and 41807417), and Natural Science Foundation of the Jiangsu Province for the Young Research Fellow (No. BK20181106). We thank Wei He (Institute of Culture Relics Reservation of Xizang Autonomous Region), Junyi Ge and Xiaolin Zhang (Institute of Vertebrate Paleontology and Paleoanthropology, Chinese Academy of Sciences) for the logistic help during the field sampling.

\section{REFERENCES}

Ahlborn M, Haberzettl T, Wang JB, Fürstenberg S, Mäusbacher R, Mazzocco J, Pierson J, Zhu LP and Frenzel P, 2016. Holocene lake level history of the Tangra Yumco lake system, southern-central Tibetan Plateau. The Holocene 26(2): 176-187, DOI 10.1177/0959683615596840.

Aitken MJ, 1998. An Introduction to Optical Dating: The Dating of Quaternary Sediments by the Use of Photon-stimulated Luminescence. Oxford University Press, Oxford.

Alivernini M, Lai ZP, Frenzel P, Fürstenberg S, Wang JB, Guo Y, Peng P, Haberzettl T, Börner N and Mischke S, 2018. Late quaternary lake level changes of Taro Co and neighbouring lakes, southwestern Tibetan Plateau, based on OSL dating and ostracod analysis. Global and Planetary Change 166: 1-18, DOI 10.1016/j.gloplacha.2018.03.016.

An ZS, Colman SM, Zhou WJ, Li XQ, Brown ET, Timothy Jull AJ, Cai YJ, Huang YS, Lu XF, Chang H, Song YG, Sun YB, Xu H, Liu WG, Jin ZD, Liu XD, Cheng P, Liu Y, Ai L, Li XZ, Liu XJ, Yan LB, Shi ZG, Wang XL, Wu P, Qiang XK, Dong JB, Lu FY and Xu $\mathrm{XW}, 2012$. Interplay between the Westerlies and Asian monsoon recorded in Lake Qinghai sediments since $32 \mathrm{ka}$. Scientific Reports 2: 619, DOI 10.1038/srep00619.

Auclair M, Lamothe M and Huot S, 2003. Measurement of anomalous fading for feldspar IRSL using SAR. Radiation Measurements 37(4-5): 487-492, DOI 10.1016/s1350-4487(03)00018-0.

Balescu S and Lamothe M, 1994. Comparison of TL and IRSL age estimates of feldspar coarse grains from waterlain sediments. Quaternary Science Reviews 13(5): 437-444, DOI 10.1016/02773791(94)90056-6.

Benson LV and Paillet FL, 1989. The use of total lake-surface area as an indicator of climatic change: examples from the Lahontan basin. Quaternary Research 32(3): 262-275, DOI 10.1016/00335894(89)90093-8.

Buylaert JP, Jain M, Murray AS, Thomsen K J, Thiel C and Sohbati R 2012. A robust feldspar luminescence dating method for Middle and Late Pleistocene sediments. Boreas 41(3): 435-451, DOI 10.1111/j.1502-3885.2012.00248.x.

Buylaert JP, Murray AS, Thomsen KJ and Jain M, 2009. Testing the potential of an elevated temperature IRSL signal from K-feldspar. Radiation Measurements 44(5-6): 560-565, DOI 10.1016/j.radmeas.2009.02.007.

Buylaert JP, Murray AS, Gebhardt AC, Sohbati R, Ohlendorf C, Thiel C, Wastegård S, Zolitschka B and The PASADO Science Team, 2013. Luminescence dating of the PASADO core 5022-1D from Laguna Potrok Aike (Argentina) using IRSL signals from feldspar. 
Quaternary Science Reviews 71: 70-80, DOI 10.1016/j.quascirev.2013.03.018.

Cai YJ, Zhang HW, Cheng H, An ZS, Edwards RL, Wang XF, Tan LC, Liang FY, Wang J and Kelly M, 2012. The Holocene Indian monsoon variability over the southern Tibetan Plateau and its teleconnections. Earth and Planetary Science Letters 335-336: 135-144, DOI 10.1016/j.epsl.2012.04.035.

Cheung MC, Zong YQ, Zheng Z, Liu ZH and Aitchison JC, 2017. Holocene temperature and precipitation variability on the central Tibetan Plateau revealed by multiple paleo-climate proxy records from an alpine wetland sequence. The Holocene 27(11): 16691681, DOI 10.1177/0959683617702225.

Chen, YW, Zong, YQ, Li B, Li SH and Aitchison J C, 2013. Shrinking lakes in Tibet linked to the weakening Asian monsoon in the past 8.2ka. Quaternary Research 80(2): 189-198, DOI 10.1016/j.yqres.2013.06.008.

Duller GAT, 2003. Distinguishing quartz and feldspar in single grain luminescence measurements. Radiation Measurements 37(2): 161165, DOI 10.1016/s1350-4487(02)00170-1.

Duller GAT, 1994. Luminescence dating of sediments using single aliquots: New procedures. Quaternary Science Reviews 13(2): 149-156, DOI 10.1016/0277-3791(94)90041-8.

Gu ZY, Liu JQ, Yuan BY, Liu RM and Liu Y, 1993. Monsoon variations of the Qinghai-Xizang plateau during the last 12000 YearsGeochemical evidence from the sediments in the Siling lake. Chinese Science Bullet 38: 577-581.

Guérin G, Mercier N and Adamiec G, 2011. Dose-rate conversion factors: update. Ancient TL 29: 5-8.

Gyawali AR, Wang JB, Ma QF, Wang Y, Xu T, Guo Y and Zhu LP, 2019. Paleo-environmental change since Late Glacial inferred from lacustrine sediment in Selin Co, central Tibet. Palaeogeography, Palaeoclimatology, Palaeoecology, 516: 101-112, DOI 10.1016/j.palaeo.2018.11.033.

Hansen V, Murray AS, Buylaert JP, Yeo EY and Thomsen K, 2015. A new irradiated quartz for beta source calibration. Radiation Measurements 81: 123-127, DOI 10.1016/j.radmeas.2015.02.017.

He Y, Hou JZ, Brown ET, Xie SY and Bao ZY, 2017. Timing of the Indian Summer Monsoon onset during the early Holocene: Evidence from a sediment core at Linggo Co, central Tibetan Plateau. The Holocene 28(5): 755-766, DOI 10.1177/0959683617744267.

Herzschuh U, 2006. Palaeo-moisture evolution in monsoonal Central Asia during the last 50,000 years. Quaternary Science Reviews 25: 163-127, DOI 10.1016/j.quascirev.2005.02.006.

Hou JZ, D'Andrea WJ and Liu ZH, 2012. The influence of ${ }^{14} \mathrm{C}$ reservoir age on interpretation of paleolimnological records from the Tibetan Plateau. Quaternary Science Reviews 48(10): 67-79, DOI 10.1016/j.quascirev.2012.06.008.

Huntley DJ and Baril MR, 1997. The K content of K-feldspars being measured in optical dating or in thermoluminescence dating. Ancient TL 15: 11-13.

Huntley DJ and Hancock RGV, 2001. The Rb contents of the Kfeldspars being measured in optical dating. Ancient TL 19: 43-46.

Huntley DJ and Lamothe M, 2001. Ubiquity of anomalous fading in Kfeldspars and the measurement and correction for it in optical dating. Canadian Journal of Earth Sciences 38(7): 1093-1106, DOI 10.1139/e01-013.

Kashiwaya K, Masuzawa T, Morinaga H, Yaskawa K, Yuan BY, Liu JQ and Gu ZY, 1995. Changes in hydrological conditions in the central Qing-Zang (Tibetan) Plateau inferred from lake bottom sediments. Earth and Planetary Science Letters 135: 31-39, DOI 10.1016/0012-821X(95)00136-Z.

Kasper T, Haberzettl T, Wang JB, Daut G, Doberschütz S, Zhu LP and Mäusbacher R, 2015. Hydrological variations on the central Tibetan Plateau since the Last Glacial Maximum and their teleconnection to inter-regional and hemispheric climate variations. Journal of Quaternary Science 30(1): 70-78, DOI 10.1002/jqs.2759.

Krause P, Biskop S, Helmschrot J , Flügel W-A, Kang, S and GaoT, 2010. Hydrological system analysis and modelling of the Nam Co basin in Tibet. Advances in Geosciences 2729: 29-36, DOI 10.5194/adgeo-27-29-2010.
Kong P, Na CG, Brown R, Fabel D, Freeman S, Xiao W and Wang YJ, 2011. Cosmogenic ${ }^{10} \mathrm{Be}$ and ${ }^{26} \mathrm{Al}$ dating of paleolake shorelines in Tibet. Journal of Asian Earth Sciences 41(3): 263-273, DOI 10.1016/j.jseaes.2011.02.016.

Li DW, Li YK, Ma BQ, Dong, GC, Wang, LQ and Zhao JX, 2009. Lake-level fluctuations since the Last Glaciation in Selin Co (lake), Central Tibet, investigated using optically stimulated luminescence dating of beach ridges. Environmental Research Letters 4: 045204, DOI 10.1088/1748-9326/4/4/045204.

Long H, Haberzettl T, Tsukamoto S, Shen, J, Kasper T, Daut G, Zhu LP, Mäusbacher R and Frechen M, 2015. Luminescence dating of lacustrine sediments from Tangra Yumco (southern Tibetan Plateau) using post-IR IRSL signals from polymineral grains. Boreas 44(1): 139-152, DOI 10.1111/bor.12096.

Long H, Lai ZP, Frenzel P, Fuchs M and Haberzettl T, 2012. Holocene moist period recorded by the chronostratigraphy of a lake sedimentary sequence from Lake Tangra Yumco on the south Tibetan Plateau. Quaternary Geochronology 10(10): 136-142, DOI 10.1016/j.quageo.2011.11.005.

Long H, Lai ZP, Wang NA and Zhang JR, 2011. A combined luminescence and radiocarbon dating study of Holocene lacustrine sediments from arid northern China. Quaternary Geochronology 6(1): 1-9, DOI 10.1016/j.quageo.2010.06.001.

Ma RH, Yang GS, Duan HT, Jiang JH, Wang SM, Feng XZ, Li AN, Kong FX, Xue B, Wu, JL and Li SJ, 2011. China's lakes at present: number, area and spatial distribution. Science in China Series D 54: 283-289 (in Chinese).

Madsen AT, Buylaert JP and Murray AS, 2011. Luminescence dating of young coastal deposits from New Zealand using feldspar. Geochronometria 38(4): 379-390, DOI 10.2478/s13386-011-0042-5.

Murray AS and Wintle AG, 2000. Luminescence dating of quartz using and improved single-aliquot regenerative protocol. Radiation Measurements 32(1): 57-73, DOI 10.1016/S1350-4487(99)00253-X.

Murray AS, Thomsen KJ, Masuda N, Buylaert JP and Jain M, 2012. Identifying well-bleached quartz using the different bleaching rates of quartz and feldspar luminescence signals. Radiation Measurements 47(9): 688-695, DOI 10.1016/j.radmeas.2012.05.006.

Rades EF, Tsukamoto S, Frechen M, Xu Q and Ding L, 2015. A lakelevel chronology based on feldspar luminescence dating of beach ridges at Tangra Yum Co (southern Tibet). Quaternary Research 83(3): 469-478, DOI 10.1016/j.yqres.2015.03.002.

Reheis MC, Adams KD, Oviatt CG and Bacon SN, 2014. Pluvial lakes in the great basin of the western United States - a view from the outcrop. Quaternary Science Reviews 97(1): 33-57, DOI 10.1016/j.quascirev.2014.04.012.

Reimann T and Tsukamoto S, 2012. Dating the recent past ( $<500$ years) by post-IR IRSL feldspar - Examples from the North Sea and Baltic Sea coast. Quaternary Geochronology 10(10): 180-187, DOI 10.1016/j.quageo.2012.04.011

Reimer PJ, Bard E, Bayliss A, Beck JW, Blackwell PG, Ramsey CB, Buck CE, Cheng H, Edwards RL, Friedrich M, Grootes PM, Guiderson TP, Haflidason H, Hajdas I, Hatté C, Heaton TJ, Hoffmann DL, Hogg AG, Hughen KA, Kaiser KF, Kromer B, Manning SW, Niu M, Reimer RW, Richards DA, Scott EM, Southon JR, Staff RA, Turney CSM and Plicht JV, 2013. INTCAL 13 and MARINE 13 radiocarbon age calibration curves $0-50,000$ years cal BP. $R a$ diocarbon 55(4): 1869-1887.

Roberts HM, 2012. Testing Post-IR IRSL protocols for minimising fading in feldspars, using Alaskan loess with independent chronological control. Radiation Measurements, 47(9): 716-724, DOI 10.1016/j.radmeas.2012.03.022.

Preusser F, Chithambo ML, Götte T, Martini M, Ramseyer K, Sendezera EJ, Susino GJ and Wintle AG, 2009. Quartz as a natural luminescence dosimeter. Earth Science Reviews 97(1-4): 184-214, DOI 10.1016/j.earscirev.2009.09.006.

Prescott JR and Hutton JT, 1994. Cosmic ray contributions to dose rates for luminescence and ESR dating: large depths and long-term time variations. Radiation Measurements 23(2-3): 497-500, DOI 10.1016/1350-4487(94)90086-8

Shi XH, Kirby E, Furlong KP, Meng K, Robinson R, Lu HJ and Wang EC, 2017. Rapid and punctuated Late Holocene recession of Siling 
Co, central Tibet. Quaternary Science Reviews 172(15): 15-31, DOI 10.1016/j.quascirev.2017.07.017.

Song CQ, Huang B and Ke LH, 2013. Modeling and analysis of lake water storage changes on the Tibetan Plateau using multi-mission satellite data. Remote Sensing of Environment 135: 25-35, DOI 10.1016/j.rse.2013.03.013.

Thomsen KJ, Murray AS, Jain M and Bøtter-Jensen L, 2008. Laboratory fading rates of various luminescence signals from feldspar-rich sediment extracts. Radiation Measurements 43(9-10): 1474-1486, DOI 10.1016/j.radmeas.2008.06.002.

Tong K, Su FG and Xu BQ, 2016. Quantifying the contribution of glacier-melt water in the expansion of the largest lake in Tibet. Journal of Geophysical Research 121: 11158-11173, DOI 10.1002/2016JD025424.

Wang SM and Dou HS, 1998. Lakes in China. Science Publisher, Beijing: $580 \mathrm{pp}$ (in Chinese).

Xue L, Zhang ZQ, Liu WM, Lv TY and Sun JM, 2010. The shrinking process of Siling Co in the past $12 \mathrm{ka}-$ Based on OSL dating of past shorelines. Chinese Journal of Geology 45(2): 428-439 (in Chinese).

Zhang EL, Chang J, Cao YM, Sun WW, Shulmeister J, Tang HQ, Langdon PG, Yang XD and Shen J, 2017. Holocene highresolution quantitative summer temperature reconstruction based on subfossil chironomids from the southeast margin of the Qinghai-Tibetan Plateau. Quaternary Science Reviews 165(1): 1-12, DOI 10.1016/j.quascirev.2017.04.008

Zhang J, Tsukamoto S, Nottebaum V, Lehmkuhl $\mathrm{F}$ and Frechen M, 2015. De plateau and its implications for post-IR IRSL dating of polymineral fine grains. Quaternary Geochronology 30: 147-153, DOI 10.1016/j.quageo.2015.02.003.

Zhang JR, Tsukamoto S, Jia YL and Frechen M, 2016. Lake level reconstruction of Huangqihai lake in northern China since MIS 3 based on pulsed optically stimulated luminescence dating. Journal of Quaternary Science 31(3): 225-238, DOI 10.1002/jqs.2861.

Zhang YS, Yao TD and Ma YZ, 2011. Climatic changes have led to significant expansion of endorheic lakes in Xizang (Tibet) since 1995. Sciences in Cold and Arid Regions 03(6): 0463-0467, DOI 10.3724/SP.J.1226.2011.00463.

Zhou J, Wang L, Zhang YS, Guo YH, Li XP and Liu WB, 2015. Exploring the water storage changes in the largest lake (Selin Co) over the Tibetan Plateau during 2003-2012 from a basin-wide hydrological modeling. Water Resources Research 51(10): 8060 8086, DOI 10.1002/2014WR015846.

Zhu DG, Meng XG, Zhao XT, Shao ZG, Xu ZF, Yang CB, Ma ZB, Wu $\mathrm{ZH}, \mathrm{Wu} \mathrm{ZH}$ and Wang JP, 2004. Evolution of an Ancient Large Lake in the southeast of the Northern Tibetan Plateau. Acta Geologica Sinca 78(4): 982-992. 